\title{
ANALISIS PEMETAAN PENILAIAN RESPONDEN TERHADAP ATRIBUT VIDEO PENYULUHAN KOMODITAS CABAI DI DESA TITIAN RESAK KECAMATAN SEBERIDA KABUPATEN INDRAGIRI HULU
}

\author{
Febrina Ayuningtyas*, Fajar Restuhadi, Deby Kurnia \\ Jurusan Agribisnis, Fakultas Pertanian, Universitas Riau \\ Jl. HR. Subrantas. Km 12.5 Simpang Baru Kode Pos 28293, Pekanbaru \\ *Corresponding author: Febrinaayuningtyas97@gmail.com
}

\begin{abstract}
This research aims to identify the level of farmers 'interest in 8 types of chili commodity extension videos, as well as identifying and analyzing attributes that affect the appeal of extension videos. The research was conducted in the village of Titian Resak, with consideration of the village is one of the villages that has many farmers and has an active farmers group. The samples in this research were 100 novice and advanced farmers and 12 people in multimedia, extension and communication. This research is a social experiment research by assessing 8 videos about chili cultivation. Sensory analysis is hedonic testing and descriptive testing. Cluster analysis (AHC) of the hedonic test and the PCA analysis of the descriptive test are further analyzed using the preference mapping technique. The results of the research showed the sensory data analysis sourced from the panelists positioning the number 8 video to be a video extension of chili commodities with the highest favorite level of $86 \%$ with the average cluster rating of 6.53 (very fond) and has characteristic of the story, transition, audio, narrative, sound effect, back sound, movie, visual, color and duration. The results of this research are as a reference material in aligning relationships
\end{abstract}

Keywords: favorite, video attributes, extension video, preference mapping

\begin{abstract}
Abstrak: Penelitian ini bertujuan untuk mengidentifikasi tingkat kesukaan petani terhadap 8 jenis video penyuluhan komoditas cabai, serta mengidentifikasi dan menganalisis daya tarik video penyuluhan. Penelitian dilakukan di Desa Titian Resak, dengan pertimbangan desa tersebut merupakan salah satu desa yang memiliki banyak petani dan memiliki kelompok tani yang aktif. Sampel pada penelitian ini adalah 100 petani pemula dan lanjutan dan 12 orang expert di bidang multimedia, penyuluhan dan komunikasi. Penelitian ini merupakan penelitian eksperimen sosial dengan menilai 8 video tentang budidaya tanaman cabai. Analisis sensori yang dilakukan adalah uji hedonik dan uji deskriptif. Analisis cluster (AHC) dari uji hedonik dan analisis PCA dari uji deskriptif selanjutnya dianalisis dengan menggunakan teknik Preference mapping. Hasil penelitian menunjukan analisis data sensori yang bersumber dari para panelis memposisikan video nomor urut 8 menjadi video penyuluhan komoditas cabai dengan tingkat kesukaan paling tinggi yaitu sebesar $86 \%$ dengan rata-rata penilaian cluster sebesar 6,53 (sangat suka) dan memiliki karakteristik atribut kisah cerita, transisi, audio, narasi, sound effect, back sound, movie, visual, warna dan durasi.
\end{abstract}

Kata Kunci: kesukaan, atribut video, video penyuluhan, pemetaan kesukaan

\section{PENDAHULUAN}

Kemajuan teknologi dalam bidang pertanian semakin pesat, baik teknologi produksi maupun teknologi sosial ekonomi. Teknologi dan informasi yang berkaitan dengan hal-hal tersebut perlu disalurkan dengan cepat dari sumber pesan kepada sasaran, yakni petani dan keluarganya serta masyarakat pertanian lainnya. Oleh karena itu, peranan media 
penyuluhan semakin penting saat ini dalam dunia pertanian (Hasanah, 2013).

Media penyuluhan pertanian berupa video saat ini sudah banyak dimanfaatkan, baik oleh penyuluh maupun petani. Video penyuluhan dapat menyalurkan pesan atau informasi dari penyuluh kepada sasaran yakni petani dan keluarganya sehingga sasaran dapat menerapkan pesan dengan kebutuhannya. Secara umum dapat dikatakan bahwa media penyuluhan berupa video merupakan suatu perantara yang digunakan untuk proses belajar dalam penyuluhan pertanian untuk memperjelas informasi yang disampaikan sehingga dapat merangsang fikiran, perasaan, perhatian dan kemampuan para petani yang ada di tiap-tiap kelompok tani, khususnya petani yang ada di Desa Titian Resak, Kecamatan Seberida, Kabupaten Indragiri Hulu.

Penggunaan media video akan membantu memperjelas informasi yang disampaikan kepada penggunanya, karena dapat lebih menarik, lebih interaktif, dapat mengatasi batasan ruang, waktu dan indera manusia (Putri, 2016). Seperti Penyuluh di Desa Titian Resak, Kecamatan Seberida, Kabupaten Indragiri Hulu, yang juga telah menggunakan media audiovisual dalam menyampaikan informasi kepada petani. Sehingga muncul hal yang menarik untuk diteliti lebih lanjut tentang bagaimana penilaian petani terhadap sebuah video, apakah terdapat faktor-faktor yang menjadi sebab akibat untuk dijadikan acuan penyuluh dalam upaya mengembangkan sebuah video yang lebih disukai petani, hal ini dapat dilihat dari atributatribut yang terdapat dalam sebuah video. Atribut dalam sebuah video adalah hal yang perlu diperhatikan dalam pembuatan video karena dapat mempengaruhi daya tarik dari video tersebut.

Pemetaan kesukaan (preference mapping) merupakan sebuah teknik yang digunakan secara luas untuk membantu peneliti memahami atribut sensori ke arah kesukaan konsumen (Stone dan Sidel, 2004). Metode ini dapat digunakan pada bidang pemasaran di suatu perusahaan maupun di bidang penelitian dan pengembangan. Analisis ini memerlukan dua jenis data yaitu data deskriptif dari pengamatan atribut sensori dan data kesukaan konsumen yang mana kedua data ini nantinya akan saling berhubungan dalam menjelaskan karakteristik sensori yang diharapkan atau diinginkan oleh konsumen (Afrianto, 2017; Berna, et al. (2005); Bonany, et al., 2014). Teknik ini juga diharapkan mampu untuk mengetahui pemetaan kesukaan kelompok tani terhadap video penyuluhan yang diberikan dan penilaian para expert terhadap atribut yang ada didalam video.

Penelitian ini bertujuan untuk mengidentifikasi tingkat kesukaan petani terhadap 8 jenis video penyuluhan komoditas cabai dan mengidentifikasi serta menganalisis atribut yang mempengaruhi daya tarik video penyuluhan.

\section{METODE PENELITIAN}

\section{Tempat dan Waktu}

Penelitian ini dilakukan di Desa Titian Resak dan Universitas Riau dengan mengambil responden petani cabai dan expert dibidang komunikasi, multimedia dan penyuluhan. Penelitian ini dilaksanakan selama enam bulan dimulai dari bulan Oktober 2018 sampai dengan bulan April 2019.

\section{Bahan dan Metode Pengambilan Sampel}

Bahan yang digunakan dalam penelitian ini adalah 8 (delapan) jenis video penyuluhan komoditas cabai dengan tema yang sama dan berdurasi rata-rata 5-9 menit.

1) Video 1 :"Budidaya Cabai Rawit", dengan durasi 9 menit 21 detik (https://www.youtube.com/watch?v=RTjNl nCAW70)

2) Video 2 :"Budidaya Cabai Hias IPB dalam Pot", dengan durasi 4 menit 35 detik (https://www.youtube.com/watch?v=bRUK ejSyBBo)

3) Video 3 :"Budidaya Cabai Melimpah", dengan durasi 3 menit 43 detik (https://www.youtube.com/watch? v=jRjKn9 DvGMw)

4) Video 4 :"Budidaya Cabai yang Baik dan Benar", dengan durasi 6 menit 18 detik (https://www.youtube.com/watch?v=t6QXF -XlpNY)

5) Video 5 :"Budidaya Cabai yang Mudah dan Cepat", dengan durasi 4 menit 20 detik (https://www.youtube.com/watch?v=oIZzIv 2xRVU)

6) Video 6 :"Pedoman Teknis Budidaya Tanaman Cabai", dengan durasi 7 menit 17 
detik (https://www.youtube.com/watch? $\mathrm{v}=\mathrm{r} 7$ VfAR2VTis)

7) Video 7 :"Pemeliharaan Tanaman Cabai", dengan durasi 4 menit 4 detik (https://www.youtube.com/watch?v=G0om1 mqh4sM)

8) Video 8 :"Sukses Tanam Cabai 20 Ton/Ha", dengan durasi 7 menit 2 detik (https://www.youtube.com/watch?v=eLsRaf $68 \mathrm{IbY})$

Sampel yang digunakan dalam penelitian ini yaitu expert dan petani. Expert berasal dari bidang penyuluhan, multimedia, komunikasi dan informatika yaitu sebanyak 12 orang. Expert memiliki tugas untuk menilai atribut video dalam penelitian. Adapun teknik pengambilan expert yaitu secara purposive sampling. Sedangkan sampel petani bertugas memberikan penilaian kesukaan terhadap 8 jenis video. Jumlah petani yang dijadikan sampel yaitu sebanyak 100 orang. Adapun teknik pengambilan sampel petani yaitu secara simple random sampling.

\section{Jenis Data}

Jenis data yang digunakan dalam penelitian ini terdiri atas data primer dan sekunder, baik bersifat kualitatif maupun kuantitatif. Data primer diperoleh melalui observasi dan wawancara langsung dengan menggunakan daftar pertanyaan (kuesioner) sebagai alat bantu yang telah disusun sesuai dengan tujuan. Data sekunder diperoleh dari studi pustaka dan data instansi.

\section{Analisis Data}

Adapun dalam penelitian, dilakukan 2 uji yaitu uji hedonik dan uji deskriptif. Uji hedonik digunakan untuk menentukan video penyuluhan mana yang paling disukai petani atau pun tidak disukai. Hasil pengujian hedonik pada penelitian ini dianalisis dengan menggunakan Agglomerative Hierarchical Clustering (AHC) melalui aplikasi XLSTAT versi 2014 untuk melihat pengelompokan panelis yang berdasarkan masing-masing cluster dan menggambarkan kesukaan mereka terhadap setiap sampel video penyuluhan.

Uji deskriptif yang dilakukan oleh expert bertujuan untuk menentukan gambaran karakteristik atribut yang ada didalam video. Dalam pelaksanaannya, expert menonton video dan memberikan penilaian terhadap video dari kelengkapan atribut-atribut yang ada seperti kisah cerita, transisi, narasi, sound effect, dialog, video effect, dialog, audio, media bergerak, animasi, movie, visual, layout design, tipografi, warna dan durasi. Hasil pengujian deskriptif pada penelitian ini dianalisis dengan menggunakan Principal Component Analysis (PCA) melalui aplikasi XLSTAT versi 2014 untuk melihat persebaran atribut pada video.

Hasil AHC dari uji hedonik dan hasil PCA dari uji deskriptif selanjutnya dianalisis dengan menggunakan teknik preference mapping. Preference mapping ditujukan untuk melihat penilaian yang menonjol pada video penyuluhan yang dilihat dari hubungan data kesukaan responden dengan karakteristik atribut (deskriptif) suatu video yang dinilai oleh petani yang disuluh.

\section{HASIL DAN PEMBAHASAN}

\section{Penyuluhan di Desa Titian Resak}

Media penyuluhan merupakan saluran yang penting guna tercapainya suatu tujuan dalam komunikasi pertanian, dimana media dapat menghubungkan penyuluh dengan materi penyuluhannya kepada petani yang memerlukan penyuluhannya. Setiap media mempunyai karakteristik yang berbeda. Media yang paling efektif dikondisi tertentu, belum tentu efektif pada kondisi yang lain. Masingmasing golongan media itu mempunyai keunggulan dan kelemahan serta karakteristik yang berbeda. Berikut empat media penyuluhan yang ada di Desa Titian Resak, Kecamatan Seberida: Video, slide powerpoint, brosur dan Penyuluh Pertanian Lapangan (PPL).

Penggunaan media video maupun slide powerpoint digunakan penyuluh ketika memberikan informasi terbaru kepada kelompok tani guna untuk mempermudah dalam menyampaikan informasi tersebut. Adapun dalam pelaksanaannya, penyuluhan dilakukan atas permintaan kelompok tani yang bertempat di rumah ketua kelompok tani dengan frekuensi sebanyak 2 kali dalam sebulan. Materi yang disampaikan oleh penyuluh disesuaikan dengan permintaan kelompok, contohnya cara pemupukan tanaman yang baik dan benar dan lain-lain. 


\section{Proses Eksperimen di Lapangan}

Proses eksperimen pada petani dimulai dengan menemui penyuluh pertanian yang bertugas di Desa Titian Resak untuk meminta data-data tentang kelompok tani. Kemudian setelah diperoleh data-data nama kelompok tani, selanjutnya bersama penyuluh menemui ketua kelompoktani untuk mengatur pertemuan bersama anggota kelompok lainnya. Setelah satu minggu, setiap ketua kelompok tani menghubungi penyuluh untuk menyepakati hari pertemuan. Pertemuan dengan setiap kelompoktani berlangsung selama kurang lebih satu bulan. Dalam satu minggu, penulis bersama penyuluh dapat menemui dua kelompoktani dihari yang berbeda. Tiap pertemuan dihadiri oleh satu kelompoktani yang berjumlah kurang lebih 10-15 orang petani. Ketika memulai penyuluhan, pembicaraan dibuka oleh penyuluh, selanjutnya penyuluh mempersilahkan kepada penulis untuk mengutarakan maksud dan tujuan kepada petani. Selanjutnya, disebarkan kuesioner kepada petani dan menjelaskan cara pengisian kuesioner serta teknis penayangan video. Adapun teknis penayangan dan penilaian yaitu petani menonton satu video kemudian menilai sesuai tingkat kesukaannya, serta memberikan alasan terhadap penilaiannya tersebut sampai ke video terakhir. Ketika petani mulai bosan, penulis mempersilahkan kepada petani untuk mencicipi hidangan yang telah disiapkan, kemudian penayangan dan penilaian dilakukan kembali hingga video terakhir.

Proses eksperimen dengan expert berbeda dengan petani. Pertemuan dilakukan secara personal, dimana penulis meghubungi expert untuk menyepakati hari pertemuan. Kemudian dihari yang telah disepakati, penulis bertemu dengan expert kemudian memberikan kuesioner dan menjelaskan teknis penilaian dan penayangan video. Berbeda halnya dengan petani, petani hanya memberikan penilaian kesukaan terhadap video dengan skala 1-7, sedangkan expert memberikan penilaian terhadap 16 atribut yang ada di setiap video. Rata-rata dari expert meminta untuk menonton video dirumah masing-masing dengan alasan agar lebih fokus dalam memberikan penilaian terhadap video.

\section{Uji Hedonik Menggunakan Agglomerative Hierarchical Clustering}

Uji hedonik atau uji preferensi dilakukan untuk mengetahui tanggapan pribadi tentang kesukaan atau ketidaksukaan dari panelis, selain itu panelis juga mengemukakan tingkat kesukaannya dengan skala hedonik. Dalam penelitian ini, data yang diuji hedonikkan yaitu penilaian kesukaan petani terhadap 8 (delapan) video komoditas cabai yang ditayangkan kepada petani. Data hedonik kemudian diolah dengan menggunakan AHC untuk melihat pengelompokan data sedemikian rupa sehingga data yang berada dalam kelompok yang sama memiliki sifat yang relatif homogen daripada data yang berada dalam kelompok yang berbeda.

Rata-rata hasil penilaian hedonik burger prebiotik secara keseluruhan oleh panelis berdasarkan pengelompokan masing-masing kelas dapat dilihat pada Tabel 1 .

Tabel 1. Rata-Rata Hasil Penilaian Uji Hedonik Berdasarkan Pengelompokan Panelis Masing-Masing Cluster Menggunakan AHC

\begin{tabular}{cccccccccc}
\hline Cluster & $\begin{array}{c}\text { Jumlah } \\
\text { panelis }\end{array}$ & V1 & V2 & V3 & V4 & V5 & V6 & V7 & V8 \\
& 8 & 5,25 & 4,37 & 5,75 & 4,37 & 6,37 & 5,87 & 6,12 & 6,75 \\
C1 & 12 & 5,75 & 4,66 & 5,66 & 5,83 & 5,25 & 6,25 & 6,33 & 6,91 \\
C2 & 4 & 6,25 & 2 & 5,5 & 6,75 & 6 & 4,25 & 5,25 & 6,5 \\
C3 & 5 & 6,2 & 6 & 6,4 & 6,2 & 6 & 5,4 & 6 & 5,6 \\
C4 & 8 & 4,87 & 5,37 & 4,25 & 3,5 & 5,87 & 6,62 & 6,37 & 6,5 \\
C5 & 46 & 5,82 & 2,95 & 2,91 & 4,76 & 5,86 & 6 & 6,32 & 6,8 \\
C6 & 17 & 5,23 & 4,82 & 3,05 & 5,52 & 5,41 & 6 & 6,23 & 6,7 \\
C7 & 100 & 5,62 & 4,31 & 4,78 & 5,27 & 5,82 & 5,77 & 6,08 & 6,53 \\
\hline Rata-rata & 10,69 &
\end{tabular}

Keterangan: Skor uji hedonik: $7=$ sangat suka; $6=$ suka; $5=$ agak suka; $4=$ netral; $3=$ agak tidak suka; $2=$ tidak suka; $1=$ sangat tidak suka. 
Tabel 1 menunjukkan bahwa V8 menghasilkan rata-rata penilaian uji hedonik secara keseluruhan yang tertinggi, yaitu sebesar 6,53 (sangat suka). Video yang memiliki penilaian tertinggi kedua adalah V7 yaitu sebesar 6,08 (suka). Selanjutnya diikuti oleh V5 sebesar 5,82 (suka), V6 sebesar 5,77 (suka), V1 sebesar 5,62 (suka), V4 sebesar 5,27 (agak suka), V3 sebesar 4,78 (agak suka) dan penilaian yang terendah adalah pada V2 yaitu sebesar 4,31 (agak suka).

Kesukaan masing-masing kelompok panelis dapat digambarkan dengan grafik spider web pada Gambar 1. Grafik spider web berikut, menunjukkan bahwa masing-masing kelompok panelis memiliki kesukaan yang berbeda pada setiap video. Hal ini dapat dilihat dari warna garis yang terdapat pada jaring labalaba, dimana garis warna terluar menunjukkan video tersebut memiliki nilai yang lebih unggul dan paling disukai daripada yang terdalam.

Cluster 1, Cluster 2, Cluster 6 dan Cluster 7, terlihat warna terluar yaitu garis warna merah jambu yang menunjukkan video 8 menjadi video yang paling disukai oleh clustercluster tersebut. Sedangkan pada Cluster 3, warna terluar yaitu garis warna ungu yang menunjukkan video 4 menjadi video yang disukai oleh panelis pada cluster tersebut. Pada Cluster 4, warna terluar yaitu garis warna hijau yang menunjukkan video 3 dan pada Cluster 5, warna terluar yaitu garis warna oren yang menunjukkan video 6 yang paling disukai.

Video 8 menjadi video dengan tingkat kesukaan tertinggi berdasarkan hasil rata-rata penilaian cluster. Hal ini dikarenakan dari 7 cluster yang ada, 4 diantaranya memberikan penilaian tertinggi pada video 8 sedangkan 3 cluster lainnya menyukai video 3, 4 dan 6 .

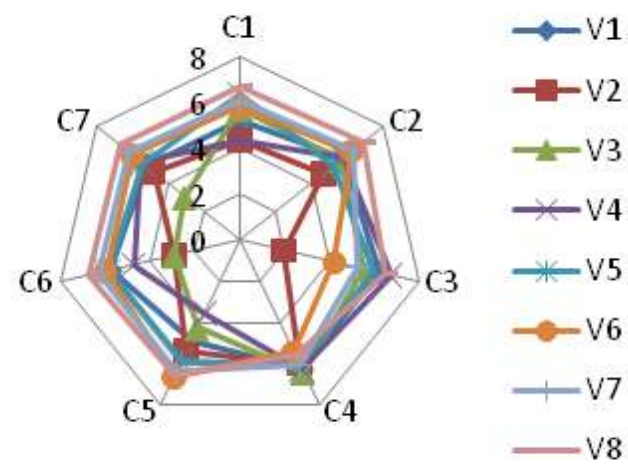

Gambar 1. Grafik spider web rata-rata penilaian kesukaan panelis berdasarkan pengelompokan masing-masing cluster.

\section{Uji Deskriptif Menggunakan Principal Component Analysis}

Tingkatan kesukaan yang telah dikemukakan oleh panelis petani, selanjutnya dapat didukung dengan uji deskriptif, dimana uji ini bertujuan untuk mengidentifikasi ingredient atau variabel proses yang bertanggung jawab terhadap karakteristik sensori atribut spesifik dari video.

Hasil penilaian oleh panelis deskriptif terhadap masing-masing atribut kisah cerita, transisi, audio, narasi, sound effect, back sound, video effect, dialog, media bergerak, animasi, movie, visual, layout design, tipografi, warna dan durasi, selanjutnya dianalisis secara statistik dengan metode PCA menggunakan software XLSTAT versi 2014 untuk melihat hubungan antar komponen utama berdasarkan penilaian masing-masing komponen atribut yang diberikan oleh para panelis.

Analisis komponen utama dilakukan untuk mengetahui ciri atau karakter yang membedakan setiap video penyuluhan komoditas cabai secara lebih spesifik, dimana dengan analisis cluster hanya mengetahui pengelompokan berdasarkan kehomogenan data, tetapi tidak mampu mengetahui dengan pasti karakter yang membedakan pengelompokan tersebut.

Setyaningsih et al. (2010) menyatakan bahwa PCA akan menghasilkan loading atau bobot kriteria penyusun komponen utama (Principal Component). Loading selanjutnya dirotasi menjadi solusi akhir. Analisis PCA menggunakan software XLSTAT menghasilkan data eigenvalue dan data korelasi serta grafik scree plot, score plot, loading plot, dan biplot. Hasil eigenvalues analisis PCA terhadap video penyuluhan komoditas cabai disajikan pada Tabel 2.

Tabel 2. Hasil Eigenvalues Principal Component Analysis

\begin{tabular}{lcccc}
\hline \multicolumn{5}{c}{ Analysis } \\
& F1 & F2 & F3 & F4 \\
\hline $\begin{array}{l}\text { Eigen } \\
\text { value }\end{array}$ & 12,4503 & 2,0250 & 0,9064 & 0,3116 \\
$\begin{array}{l}\text { Varia } \\
\text { bility } \\
(\%)\end{array}$ & 77,8143 & 12,6560 & 5,6651 & 1,9474 \\
$\begin{array}{l}\text { Cumu } \\
\text { lative } \\
\%\end{array}$ & 77,8143 & 90,4704 & 96,1355 & 98,0829 \\
\hline
\end{tabular}


Tabel 2 memperlihatkan 4 komponen utama yang memiliki nilai eigenvalue terbesar, dan nilai eigenvalue yang dipilih adalah yang memiliki nilai $\geq 1$. Setyaningsih et al. (2010) menyatakan bahwa komponen utama adalah suatu indeks yang menunjukkan ragam individu yang paling maksimum. Komponen utama 1 (penuturan, teknik visualisasi, dan transisi) merupakan komponen utama yang mempunyai variasi terbesar dari variasi total individu. Komponen utama terbesar kedua disebut komponen utama 2 (latar belakang dan durasi)

Proses pencarian komponen utama akan terus berlanjut hingga komponen utama terakhir, dimana variasi individu yang dijelaskan akan semakin kecil. Setiap komponen utama yang dihasilkan pada penelitian ini terdiri atas 16 komponen atribut yang dianalisis, yaitu kisah cerita, transisi, audio, narasi, sound effect, back sound, video effect, dialog, media bergerak, animasi, movie, visual, layout design, tipografi, warna dan durasi.

Grafik scatter plot atau disebut juga grafik biplot digunakan untuk mengetahui hubungan antara sampel video dan komponen atribut video. Grafik biplot yang dihasilkan berdasarkan analisis PCA dapat dilihat pada Gambar 2.

Hasil interpretasi dari grafik biplot berdasarkan analisis PCA pada Gambar 2 bahwa atribut tipografi, warna, animasi, video effect, layout design, durasi, media bergerak, dan sound effect berada pada kuadran yang sama (kuadran II), sehingga memiliki hubungan yang dekat antara atribut satu dengan yang lain. Sedangkan atribut back sound, audio, visual, kisah cerita, narasi, transisi, movie dan dialog sangat dekat karena samasama berada pada kuadran III.

Esbensen et al. (1994) menyatakan bahwa sampel yang berada dalam satu kuadran adalah sama dengan yang lain dan berbeda dengan sampel yang terdapat pada kuadran yang lain. Artinya sampel video yang berada pada posisi berdekatan memiliki karakteristik yang sama. Hasil PCA menunjukkan bahwa pada V1, V6 dan V7 berada pada kuadran yang sama (kuadran III) sehingga dapat dikelompokkan dengan deskripsi karakteristik khas yang sama, yaitu pada atribut back sound, audio, visual, kisah cerita, narasi, transisi, movie dan dialog. V4 dan V8 berada pada posisi yang berdekatan yakni berada dalam kuadran yang sama (kuadran II), sehingga dapat dikelompokkan dengan deskripsi karakteristik khas yang sama, yaitu pada atribut tipografi, warna, animasi, video effect, layout design, durasi, media bergerak, dan sound effect.

Dari grafik tersebut, kita dapat melihat korelasi antara video maupun atribut terhadap F1 maupun F2. Diketahui bahwa kuadran I, memiliki korelasi negatif terhadap F1 (Penuturan, teknik visualisasi dan transisi) namun berkorelasi positif terhadap F2 (latar belakang dan durasi). Kuadran II memiliki hubungan atau korelasi positif baik terhadap F1 maupun F2. Kuadran III memiliki korelasi positif terhadap F1 namun berkorelasi negatif pada F2. Sedangkan kuadran IV memiliki korelasi negatif baik pada F1 maupun F2.

Biplot (axes F1 and F2: 90,47\%)

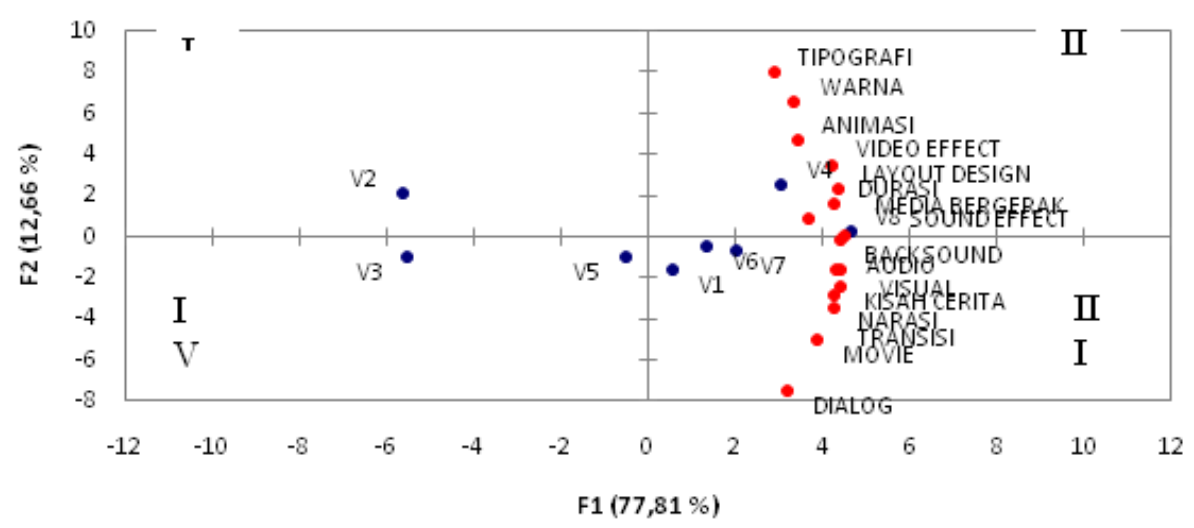

Gambar 2. Grafik biplot antara komponen utama F1 dan F2 
Esbensen et al. (1994) dan Baum (2006) menyatakan bahwa sampel yang berada dalam satu kuadran adalah sama dengan yang lain dan berbeda dengan sampel yang terdapat pada kuadran yang lain. Artinya sampel video yang berada pada posisi berdekatan memiliki karakteristik yang sama. Hasil PCA menunjukkan bahwa pada V1, V6 dan V7 berada pada kuadran yang sama (kuadran III) sehingga dapat dikelompokkan dengan deskripsi karakteristik khas yang sama, yaitu pada atribut back sound, audio, visual, kisah cerita, narasi, transisi, movie dan dialog. V4 dan V8 berada pada posisi yang berdekatan yakni berada dalam kuadran yang sama (kuadran II), sehingga dapat dikelompokkan dengan deskripsi karakteristik khas yang sama, yaitu pada atribut tipografi, warna, animasi, video effect, layout design, durasi, media bergerak, dan sound effect.

V2 dan V3 terlihat sangat jauh dari karakter atribut yang dikuantifikasi. Menurut panelis, V2 dan V3 memiliki kualitas yang rendah disemua atribut yang dikuantifikasi. Selain itu, karakteristik dari setiap video dapat dilihat dari grafik spider web pada Gambar 3.

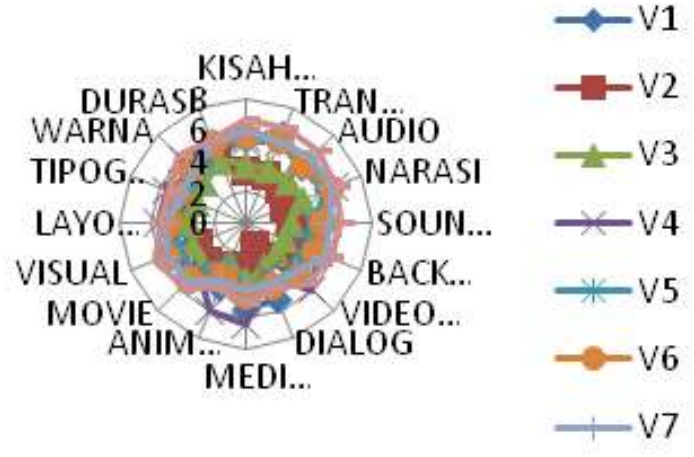

Gambar 3. Grafik spider web karakteristik atribut pada setiap video berdasarkan penilaian expert.

Grafik spider web di atas menunjukkan bahwa dari penilaian expert, V8 memiliki keunggulan pada atribut kisah cerita, transisi, audio, narasi, sound effect, back sound, movie, visual, warna, dan durasi karena atribut tersebut lebih menarik dan memiliki nilai yang lebih tinggi pada video delapan (V8) dibandingkan pada atribut dan video yang lain, sehingga garis V8 berada pada posisi terluar mendekati tiap-tiap atribut tersebut. Hal ini juga sesuai dengan tingkat kesukaan petani. Oleh karena itu, V8 menjadi video yang lebih banyak disukai petani sesuai dengan Gambar 5. Namun pada atribut video effect, media bergerak, animasi, layout design, dan tipografi, V4 lebih unggul. Adapun garis terdalam yang berarti jauh dari atribut-atribut video yaitu V2 dan V3. Oleh karena itu, video tersebut memperoleh nilai rata-rata kesukaan yang kecil dari petani.

\section{Preference Mapping}

Metode preference mapping umumnya digunakan pada sensory science dan dapat dimanfaatkan untuk memetakan pengelompokan konsumen terhadap beragam produk (internal preference mapping) atau memetakan kualitas dan karakteristik flavor makanan dari beragam produk (eksternal preference mapping). Preference mapping merupakan teknik yang menghubungkan rating kesukaan konsumen (data hedonik) dengan karakteristik sensori (data deskriptif) suatu produk (Martinez et al.,2001; Berna,et al., 2005; Bonany, et al., 2014). Preference mapping diperoleh berdasarkan analisis cluster dari hasil AHC dan analisis komponen utama dari hasil PCA.

Hasil analisis preference mapping pada penelitian ini dapat disajikan pada Gambar 4. Persentase kesukaan panelis terhadap masingmasing sampel dilihat pada Tabel 3.

Tabel 3. Urutan persentase kesukaan panelis terhadap masing-masing video

\begin{tabular}{cc}
\hline Video & Kesukaan Panelis \\
\hline V8 & $86 \%$ \\
V7 & $86 \%$ \\
V5 & $86 \%$ \\
V6 & $86 \%$ \\
V1 & $86 \%$ \\
V4 & $57 \%$ \\
V3 & $14 \%$ \\
V2 & $14 \%$ \\
\hline
\end{tabular}

Grafik preference mapping pada Gambar 4 menunjukkan pemetaan hasil penilaian panelis hedonik dan deskriptif. Dari gambar peta tersebut terlihat perbedaan persentase kesukaan panelis yang ditunjukkan dengan warna yang berbeda pada tiap video. Pada kuadran I, terlihat warna abu-abu terletak pada Video 2 yang menunjukkan kesukaan panelis terhadap video tersebut sebesar 14\%, dilihat di Tabel 3. 


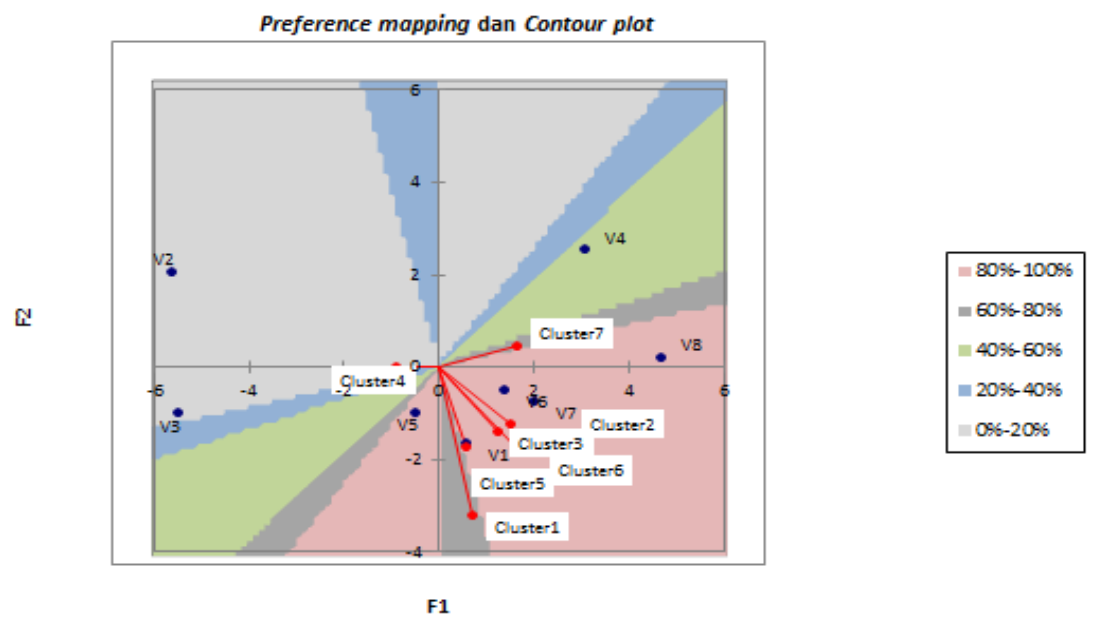

Gambar 4. Pemetaan tingkat kesukaan panelis hedonik dan deskriptif video

Video 2 menjadi video dengan tingkat kesukaan terendah, karena berdasarkan penilaian expert terhadap atribut pada Gambar 3 , terlihat bahwa Video 2 memiliki penilaian atribut terendah mendekati sumbu 0 pada atribut kisah cerita, transisi, audio, narasi, sound effect, video effect, dialog, media bergerak, animasi, movie dan visual.

Video 4 dan Video 8 terletak pada kuadran II, yang berarti memiliki kedekatan atau kemiripan karakteristik. Hal ini dapat dilihat pada gambar 3, bahwa garis antara V4 dan V8 saling berdekatan yaitu pada atribut narasi, video effect, layout design, tipografi, warna dan durasi, namun Video 8 memiliki nilai yang lebih unggul daripada Video 4. Meskipun berada pada kuadran yang sama, posisi kedua video tersebut berada pada warna yang berbeda yaitu Video 4 pada warna hijau dan Video 8 pada warna merah muda, dimana hal ini menunjukkan perbedaan kesukaan pada kedua video tersebut. Berdasarkan Tabel 3, Video 4 memiliki tingkat kesukaan sebesar 57\% sedangkan Video 8 memiliki tingkat kesukaan sebesar $86 \%$, yang diperoleh dari penilaian panelis terhadap video. Artinya, Video 8 lebih unggul dan lebih disukai oleh panelis daripada Video 4.

Kuadran III menunjukkan bahwa Video 1, 6 dan 7 saling berdekatan yang berarti memiliki karakteristik yang mirip. Hal ini dapat dilihat dari Gambar 3, dimana garis antara Video 1, 6 dan 7 saling berdekatan pada atribut transisi, narasi, movie, layout design, dan warna. Pada atribut lain, Video 6 dan 7 memiliki kedekatan pada atribut back sound, dialog, media bergerak, animasi, visual, tipografi dan durasi. Pada Gambar 4 menunjukkan bahwa hasil pemetaan memposisikan video 1,6 dan 7 berada pada warna merah muda yang memiliki persentase tingkat kesukaan sebesar $86 \%$, yang diperoleh dari hasil penilaian panelis terhadap video.

Kuadran IV menunjukkan bahwa video 3 dan 5 berada dalam satu kuadran, yang berarti memiliki kedekatan atau karakteristik yang sama. Dapat dilihat dari Gambar 3, garis antara video 3 dan 5 terlihat berdekatan yaitu pada atribut media bergerak, animasi dan warna. Meskipun berada didalam kuadran yang sama, namun jarak antara keduanya terlihat berjauhan, dimana video 5 cenderung lebih dekat pada kuadran III sedangkan video 3 cenderung lebih dekat pada kuadran I. Hal ini juga didukung oleh pemetaan warna yang berbeda antara keduanya, dimana video 3 terletak pada warna abu-abu dengan persentase tingkat kesukaan sebesar $14 \%$ dan video 5 terletak pada warna merah jambu dengan persentase tingkat kesukaan sebesar $86 \%$ yang merupakan hasil penilaian kesukaan dari panelis petani maupun expert.

Preference mapping berguna untuk
membantu mensukseskan
pengembangan produk baru dengan
menyediakan penilaian visual data hedonik
secara lebih spesifik. Preference mapping
mampu membandingkan satu set produk yang
telah dinilai tingkat kesukaannya oleh panelis
petani (pemetaan internal) dan karakteristik
yang telah dijelaskan oleh panelis deskriptif
sebagai expert (pemetaan eksternal). Dengan


preference mapping kita dapat mengetahui bahwa V7,V5, V6 dan V1 adalah video yang paling disukai setelah $\mathrm{V} 8$ oleh panelis dengan tingkat kesukaan 86\%, sedangkan V2 merupakan video yang paling tidak disukai panelis dengan tingkat kesukaan sebesar $14 \%$.

\section{KESIMPULAN DAN SARAN}

Berdasarkan hasil penelitian dengan analisis yang telah dilakukan di Desa Titian Resak, Kecamatan Seberida Kabupaten Indragiri Hulu disimpulkan bahwa:

1. Video penyuluhan cabai no urut 8 menjadi video dengan tingkat rata-rata kesukaan tertinggi yaitu sebesar 6,53 (sangat suka) karena dari 7 cluster petani yang ada, terdapat 4 cluster yang menyukai video no urut 8 dengan nilai tertinggi yaitu cluster 1, cluster 2, cluster 6 dan cluster 7.

2. Hasil analisis atribut kisah cerita, transisi, audio, narasi, sound effect, back sound, movie, visual, warna dan durasi merupakan atribut yang mempengaruhi pada video penyuluhan. Hal ini berdasarkan penilaian deskriptif dari para expert terhadap video tersebut.

Sebaiknya dalam pembuatan video penyuluhan perlu diperhatikan aspek-aspek atribut yang sesuai seperti kisah cerita, transisi, audio, narasi, sound effect, back sound, movie, visual, warna dan durasi karena atribut-atribut tersebut mempengaruhi daya tarik petani untuk melihat sebuah video.

\section{DAFTAR PUSTAKA}

Afrianto, R. 2017. Analisis Pemetaan Kesukaan Konsumen (Consumer's Preference Mapping) Terhadap Atribut Bolu Kemojo Di Kalangan Mahasiswa Fakultas Pertanian Universitas Riau. Skripsi Jurusan Teknologi Pertanian, Fakultas Pertanian. Universitas Riau.
Baum, C. F. 2006. An Introduction to Modern Econometrics Using Stata. Texas: Stata Press.

Berna, A. Z., Lammertyn, J., Buysens, S., Di Natale, C., dan Nicolas, B. M. 2005. Mapping Consumer Liking of Tomatoes with Fast Aroma Profiling Techniques. Postharvest Biology and Technology, 38( 2), 115- 127

Bonany, J., Brugger, C., Buehler, A., Carbó, J., Codarin, S., Donati, F., Schoorl, F. 2014. Preference Mapping of Apple Varieties in Europe. Food Quality and Preference, 32, 317- 329.

Esbensen, K., S. Schonkopf, dan T. Midgaard. 1994. Multivariate Analysis In Practice. Trondheim: Wennbergs Trykkeri.

Hasanah, Suswatun. 2013. Efektivitas Penyuluhan Pembuatan Pestisida Alami dari Daun Pepaya (carica papaya) Menggunakan Multimedia pada Petani di Desa Kempas Jaya Kecamatan Kempas Kabupaten Indragiri Hilir. Skripsi Jurusan Agribisnis, Fakultas Pertanian. Universitas Riau.

Martinez, C. 2001. Preference Mapping of Cracker Type Biscuits. Journal Food Quality and Preference, 1(3), 535-544.

Putri, R. (2018/09/15). Media Penyuluhan Perikanan. Retrived from http://www. Bppp-tegal.com/web/index.php/artikel/ 100-artikel/artikel-manajemen/195media-penyuluhan-perikanan.

Setyaningsih, D., Apriyantono, A., dan Sari, M.P. 2010. Analisis Sensori untuk Industri Pangan dan Agro. Bogor: Institut Pertanian Bogor Press.

Stone, H. dan Sidel, J. L. 2004. Sensory Evaluation Practices. 3rd ed. California: Elsevier Academic Press. 